\title{
Assessment of the potential for gene flow from transgenic maize (Zea mays L.) to eastern gamagrass (Tripsacum dactyloides L.)
}

\author{
Moon-Sub Lee • Eric K. Anderson • Duška Stojšin • Marc A. McPherson • \\ Baltazar Baltazar - Michael J. Horak - Juan Manuel de la Fuente •

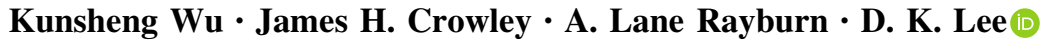

Received: 18 November 2016/ Accepted: 24 April 2017/Published online: 2 May 2017

(C) The Author(s) 2017. This article is an open access publication

\begin{abstract}
Eastern gamagrass (Tripsacum dactyloides L.) belongs to the same tribe of the Poaceae family as maize (Zea mays L.) and grows naturally in the same region where maize is commercially produced in the USA. Although no evidence exists of gene flow from maize to eastern gamagrass in nature, experimental crosses between the two species were produced using specific techniques. As part of environmental risk assessment, the possibility of transgene flow from maize to eastern gamagrass populations in nature was evaluated with the objectives: (1) to assess
\end{abstract}

Electronic supplementary material The online version of this article (doi:10.1007/s11248-017-0020-7) contains supplementary material, which is available to authorized users.

M.-S. Lee · E. K. Anderson · A. L. Rayburn ·

D. K. Lee $(\bowtie)$

Department of Crop Sciences, University of Illinois at Urbana-Champaign, 1102 S. Goodwin Ave., Urbana,

IL 61801, USA

e-mail: leedk@illinois.edu

D. Stojšin · M. A. McPherson - B. Baltazar - M. J. Horak Monsanto Company, 800 North Lindbergh Blvd.,

St. Louis, MO 63167, USA

J. M. de la Fuente

Monsanto Company, Park Plaza Torre II, 504 Javier Barros Sierra Ave., Col. Santa Fe, Del. Alvaro Obregon, CP 01210 Mexico, DF, Mexico

K. Wu $\cdot$ J. H. Crowley

Monsanto Company, 700 Chesterfield Parkway W.,

St. Louis, MO 63017, USA the seeds of eastern gamagrass populations naturally growing near commercial maize fields for the presence of a transgenic glyphosate-tolerance gene (cp4 epsps) that would indicate cross-pollination between the two species, and (2) to evaluate the possibility of interspecific hybridization between transgenic maize used as male parent and eastern gamagrass used as female parent. A total of 46,643 seeds from 54 eastern gamagrass populations collected in proximity of maize fields in Illinois, USA were planted in a field in 2014 and 2015. Emerged seedlings were treated with glyphosate herbicide and assessed for survival. An additional 48,000 seeds from the same 54 eastern gamagrass populations were tested for the presence of the cp4 epsps transgene markers using TaqMan ${ }^{\circledR} \mathrm{PCR}$ method. The results from these trials showed that no seedlings survived the herbicide treatment and no seed indicated presence of the herbicide tolerant cp4 epsps transgene, even though these eastern gamagrass populations were exposed to glyphosate-tolerant maize pollen for years. Furthermore, no interspecific hybrid seeds were produced from 135 hand-pollination attempts involving 1529 eastern gamagrass spikelets exposed to maize pollen. Together, these results indicate that there is no evidence of gene flow from maize to eastern gamagrass in natural habitats. The outcome of this study should be taken in consideration when assessing for environmental risks regarding the consequence of gene flow from transgenic maize to its wild relatives. 
Keywords Eastern gamagrass - Transgenic maize · Gene flow · Glyphosate-tolerance

\section{Introduction}

A total of 322 transgenic crop products have been approved for cultivation worldwide since its first commercialization in 1996 (ISAAA 2016). In the USA alone, 70.9 million hectares were planted with transgenic crops in 2015 with high adoption rates for maize (92\%), soybean (94\%) and cotton (94\%) (James, 2015). Gene flow as a result of outcrossing is one of the considerations of environmental risk assessment prior to commercialization of transgenic crops. The likelihood and consequences of potential pollen-mediated gene flow from transgenic crops to their wild relatives is assessed to assure that a transgene will not contribute a competitive advantage to the receiving species that might result in increased weediness and invasiveness, or in a decrease in biodiversity and disruption of ecological equilibrium (Tiedje et al. 1989; Williamson 1994; Ellstrand 2001; Gewin 2003).

When assessing for risk associated with potential pollen-mediated gene flow in nature from transgenic maize (Zea mays L.) to eastern gamagrass (Tripsacum dactyloides L.), several factors need to be considered such as shared habitats, exposure to outcrossing and sexual compatibility between the two species.

Shared habitats between eastern gamagrass and maize

Eastern gamagrass is an extremely diverse warmseason, perennial grass that grows naturally in prairie remnants and is native to North and South America. The majority of Tripsacum species have been observed in Mexico (Newell and de Wet 1974; de Wet et al. 1982; Li et al. 1999) with their habitat extending from $42^{\circ} \mathrm{N}$ in the USA to $24^{\circ} \mathrm{S}$ in South America (de Wet et al. 1982). Besides natural populations, diverse cultivars of eastern gamagrass are commonly used for forage production, erosion control and wildlife plantings in the USA (Kindiger and Dewald 1997; Springer and Dewald 2004). The regions in North and South America where eastern gamagrass grows are also significant maize production areas with a high proportion of commercially grown transgenic maize.
Exposure to outcrossing

In 2015, the area planted with transgenic maize was 33.1 million hectares in the USA, 13.1 million hectares in Brazil and 2.9 million hectares in Argentina, which jointly represent a major portion of 53.6 million hectares of transgenic maize grown globally (James 2015).

In the USA, transgenic maize with herbicidetolerance has been grown adjacent to eastern gamagrass natural populations for years, as herbicidetolerant maize made up $7 \%$ of the USA production in 2000 (Fernandez-Cornejo et al. 2014) and increased to $96 \%$ by 2015 (James 2015). Similarly, most transgenic maize grown in Brazil and Argentina in 2015 contained herbicide tolerance traits: 63 and $76 \%$, respectively (James 2015).

Commercial maize hybrids with tolerance to glyphosate (an active ingredient in the Roundup ${ }^{\circledR 1}$ agricultural herbicides) include NK603 and MON88017 transgenes. The maize hybrids containing the NK603 transgene have been commercially grown in the USA since 2001, whereas those with MON88017 transgene have been cultivated since 2005 . Both transgenes were developed by Monsanto Co. (St. Louis, MO, USA) and for both, the herbicide-tolerance is due to a production of the 5-enolpyruvylshikimate-3-phosphate synthase protein from Agrobacterium sp. strain CP4 (CP4 EPSPS) that confers tolerance to the herbicide glyphosate. The long duration of these transgenic maize products in the market and their high adoption rate by farmers have resulted in a very high exposure of eastern gamagrass populations to maize pollen with the cp4 epsps transgene in the USA Corn Belt region.

\section{Sexual compatibility}

Eastern gamagrass is a wild relative of maize and they both belong to the tribe Andropogoneae of the Poaceae family. Genetic diversity of eastern gamagrass is exemplified by different ploidy levels observed among natural populations. The three major variants are: diploid $(2 \mathrm{n}=2 \mathrm{x}=36)$, triploid $(2 \mathrm{n}=3 \mathrm{x}=54)$ and tetraploid $(2 \mathrm{n}=4 \mathrm{x}=72)$ cytotypes (Newell and de Wet 1974; de Wet et al. 1982). Pentaploid $(2 \mathrm{n}=5 \mathrm{x}=90)$ and hexaploid $(2 \mathrm{n}=6 \mathrm{x}=108)$

\footnotetext{
${ }^{1}{ }^{\circledR}$ Roundup is a registered trademark of Monsanto Technology LLC.
} 
cytotypes have also been reported (Newell and de Wet 1974; Farquharson 1955; Kindiger and Dewald 1997).

The reproductive biology of gamagrass appears to be correlated with ploidy level as diploid populations reproduce sexually, whereas polyploid populations predominantly reproduce through facultative apomixes and pseudogamy (Farquharson 1955; Newell and de Wet 1974; Burson et al. 1990; Sherman et al. 1991; Dewald and Kindiger 1994). The majority of gamagrass populations that grow naturally through the central and eastern USA are diploid and tetraploid cytotypes (Newell and de Wet 1974). Compared to eastern gamagrass (where ploidy levels range from $2 \mathrm{x}$ to $6 \mathrm{x}$ with corresponding chromosome number range from 36 to 108), maize is a diploid species with a stable chromosome number $(2 \mathrm{n}=2 \mathrm{x}=20)$ and sexual reproduction.

Outcrossing between species of different genera can occur (Raybould and Gray 1993), but it is generally lower in frequency compared to outcrossing within the same species or between species of the same genus due to a lower level of genetic compatibility. Because Tripsacum and Zea are closely related genomes, eastern gamagrass has been considered as a possible source of favorable and diverse genes for maize improvement (Newell and de Wet 1974; de Wet et al. 1982; Li et al. 1999; de Wet and Harlan 1974; Leblanc et al. 1995; Reeves and Bockholt 1964; Duvick et al. 2006; Hajjar and Hodgkin 2007). Tripsacum's wide tolerance to soil conditions, resistance to some common maize diseases and insect pests, favorable fatty acid composition and ability to reproduce through apomixis are examples of characteristics that make this species potentially valuable for maize breeding programs (Doebley 1983; Bernard and Jewell 1985; Leblanc et al. 1995; Gurney et al. 2003; Duvick et al. 2006; Belova et al. 2010).

Collins and Kempton $(1914,1916)$ attempted the first interspecific hybridization between maize and eastern gamagrass, but were not successful. Mangelsdorf and Reeves (1931) produced the first true, interspecific hybrids with maize used as the maternal parent and eastern gamagrass (both diploid and tetraploid cytotypes) as the paternal parent. However, the success of artificial hybridization was accomplished only with special techniques (Beadle 1980) such as removing husk leaves from maize ears, and cutting the maize silks to accommodate for shorter eastern gamagrass pollen tubes (Mangelsdorf and
Reeves 1931; Bernard and Jewell 1985). The shorter maize silks eliminated one of the cross-incompatibility obstacles (lack of growth support for the eastern gamagrass pollen tube within the maize silk), however there are other late-acting barriers which prevent formation of hybrid zygote in most intergeneric crosses between grasses (Dresselhaus et al. 2011). Utilization of embryo culture techniques (Randolph 1970; James 1979; Bernard and Jewell 1985) was also needed to generate these experimental hybrids between eastern gamagrass and maize. The resulting hybrid seeds were obtained at very low frequency, showed variable and highly abnormal development resulting in reduced germination and low seedling survival (Mangelsdorf and Reeves 1931). The seedlings generally exhibited retarded development with no roots or significantly delayed root system growth (Bernard and Jewell 1985). Hybrid plants that survived to flowering had complete male sterility (lack of anthers extrusion, aborted pollen grains), reduced female sterility, variability in chromosome number within the cells of the same tissue, and erratic and progressive chromosome elimination in subsequent generations (Mangelsdorf and Reeves 1931; James, 1979; Beadle 1980; Leblanc et al. 1995; Graminelli et al. 1996; Randolph 1970).

To overcome hybrid sterility, the interspecific hybrid plants needed to be backcrossed to maize producing offspring that exhibited a rapid loss of Tripsacum chromosomes and partial to high sterility even after multiple backcross generations (de Wet and Harlan 1972; Graminelli et al. 1996; Belova et al. 2010). In some studies, none of the backcrosses were successful in producing fertile plants (James 1979). This genomic instability and sterility of hybrids between maize and eastern gamagrass have been some of the factors that limited the usefulness of eastern gamagrass in maize breeding programs.

The hybrids reported in literature were generally accomplished with maize used as the female parent (Mangelsdorf and Reeves 1931; James 1979; Bernard and Jewell 1985; Leblanc et al. 1995; Duvick et al. 2006; Belova et al. 2010). When assessing the environmental risk of gene flow from transgenic maize to eastern gamagrass, the crosses where eastern gamagrass is used as a female parent would be most informative. Mangelsdorf and Reeves (1931) tried to produce interspecific hybrids using eastern gamagrass as a female parent, but were not successful. A couple 
of researchers reported producing experimental hybrids with eastern gamagrass used as pollen recipient (Farquharson 1957; de Wet et al. 1984). However most of the resulting seeds failed to germinate (Farquharson 1957). Those that germinated had abnormal seedlings that did not survive. Some seedlings were not true hybrids as they had no maize chromosome which indicated lack of fertilization (de Wet et al. 1984; Farquharson 1957). A few plants that were identified as true hybrids in these studies were not mentioned in subsequent research publications. In a comprehensive review of genetic research on Tripsacum, Blakey et al. (2007) summarized extensive hybridization effort where maize was used as a female parent, without a mention of any research with hybrids resulting from maize as a male parent.

Most experts agree that Tripsacum and maize do not naturally cross-pollinate in spite of growing in close proximity for centuries (Mangelsdorf and Reeves 1931; Randolph 1970; Beadle 1980; Dresselhaus et al. 2011). No evidence was found for ongoing natural gene introgression between maize and Tripsacum although careful and extensive research was conducted across large number of populations from Mexico, Guatemala and South America (de Wet and Harlan 1978; de Wet et al. 1981). The severely limited fertility demonstrated in experimental hybrids presents a significant biological barrier to gene flow between maize and eastern gamagrass (Eubanks 1994). However, the possibility of obtaining experimental interspecific hybrids between maize and eastern gamagrass using special greenhouse and laboratory techniques has raised the question about the probability of natural outcrossing between these two species to the attention of risk assessors/evaluators. This ambiguity prompted the Mexican Ministries of Agriculture and Environment to include areas where Tripsacum grows naturally as consideration for the isolation areas defined in the current version of the Agreement for Maize Center of Origin to prevent potential flow of transgenes from maize to Tripsacum (SAGARPA 2012).

The present research was conducted to contribute to a better scientific understanding of a possibility of gene flow from maize to eastern gamagrass in nature, and to assist decision-makers in the assessment of environmental risks regarding the likelihood and potential consequence of gene flow from transgenic maize to eastern gamagrass. The objectives of this study were: (1) to assess if the gene flow occurs in nature from cultivated transgenic maize to eastern gamagrass and (2) to evaluate the possibility of interspecific hybridization between transgenic maize used as male parent and eastern gamagrass used as female parent when aided by hand-pollination under greenhouse conditions. To our knowledge this is the first study to evaluate the potential of pollen-mediated gene flow from transgenic maize to natural populations of eastern gamagrass. The results obtained in this study are relevant to environmental risk assessment of transgenic maize in regions where maize and eastern gamagrass coexist.

\section{Materials and methods}

Assessment of gene flow from glyphosate-tolerant maize to eastern gamagrass

\section{Plant material}

Seeds collected from natural populations of eastern gamagrass growing in Illinois, USA were used in this study. At each location, seeds were collected within $50 \mathrm{~m}$ of a field where at least 40 ha of transgenic maize was cultivated in the same year. Furthermore, the area where collections were made was within the region of major commercial maize production ensuring long period of eastern gamagrass exposure to transgenic maize pollen. A total of 54 eastern gamagrass populations were sampled from August through September in both 2013 and 2014.

The populations were collected from 43 different Illinois locations. At some locations, more than one population was collected if they were found in close proximity and if they had some observed phenotypic differences that would justify classifying them as different populations (e.g., EG 211 and EG 212; EG 124 and EG 125). Also, populations were given unique names if they were collected at the same location, but in different years (e.g., EG 117 and EG 214). In most cases, only a single population of eastern gamagrass was found at a given location and in a given year.

A total of 73,930 seeds from 26 populations and 66,407 seeds from 28 populations were collected in 2013 and 2014, respectively (Table 1). Collected seed was stored at $4{ }^{\circ} \mathrm{C}$ until field screening and molecular assay. 
Field screen

A field experiment was conducted in 2014 and 2015 to determine whether natural eastern gamagrass populations exhibited tolerance to the glyphosate herbicide (S-Table 1). A total of 21,450 seeds representing 26 natural populations from 2013 collection and 25,193 seeds collected from 28 natural populations in 2014 were used in the experiment. Since eastern gamagrass is slow and difficult to establish from seed, stratification was conducted prior to planting to improve germination and emergence rate (USDA NRCS 2015). Seed stratification was conducted by following these steps: (1) collected seeds were immersed in water with fungicide (ApronMaxx RTA, Syngenta Crop Production, Inc., Greenboro, NC, USA) for $24 \mathrm{~h}$ and (2) seed was drained, placed in sealed plastic bags and maintained at $10{ }^{\circ} \mathrm{C}$ for 60 days. Stratified seeds were planted in a Flanagan silt loam soil at the University of Illinois Research Farm, Urbana, IL $\left(40^{\circ} 04^{\prime} \mathrm{N}, 88^{\circ} 13^{\prime} \mathrm{W}\right)$. Planting was conducted on April 23, 2014 and May 18, 2015 at $3 \mathrm{~cm}$ depth using a two-row plot planter. Inter-row spacing was $76 \mathrm{~cm}$. Conventional and glyphosate-tolerant maize hybrids were also planted as control checks. Seeds from each eastern gamagrass population and maize hybrid were planted in single rows, $25 \mathrm{~m}$ in length. Seedling emergence was recorded weekly for 4 weeks after planting. When seedlings of eastern gamagrass reached the 3-4 leaf stage, glyphosate was applied at $334 \mathrm{~g}$ acid equivalent (a.e.) ha ${ }^{-1}$ rate (Roundup $^{\circledR}$ Powermax, Monsanto Company, St. Louis, MO, USA) with $2 \% \mathrm{v} / \mathrm{v}$ ammonium sulfate as an additive. Maize plants were at the 6-8 leaf stage at the time of herbicide application. Plant mortality was evaluated weekly over a 2-week period. Complete mortality of conventional maize indicated that the glyphosate application was conducted correctly.

Seedlings of eastern gamagrass that emerged after the glyphosate application were transplanted into 2-L pots and allowed to grow outdoors until they reached the 3-4 leaf stage. Glyphosate was applied at the previously described rate using a $\mathrm{CO}_{2}$ backpack sprayer calibrated to deliver $168 \mathrm{~L} \mathrm{ha}^{-1}$ at $220 \mathrm{kPa}$ through a two-nozzle spray boom. Plant mortality was observed weekly over a 2-week period.
Development and validation of cp4 epsps marker

Seeds of eastern gamagrass, maize with the CP4 EPSPS trait, that confers tolerance to glyphosate, (the NK603 and MON88017 products) and conventional maize (without the transgenic CP4 EPSPS trait) were each ground on dry ice in separate batches. Material from these ground samples were used to develop a dilution series and simulate an eastern gamagrass sample with CP4 EPSPS trait from NK603 and MON88017. This method development step was conducted to ensure that even a small quantity of transgene presence could be detected in eastern gamagrass. As samples of 25, 50, 100, 200 and 400 bulked seeds were considered, the ground maize material was mixed with ground eastern gamagrass material in 1:25, 1:50, 1:100, 1:200 and 1:400 ratio. The weight used to represent gamagrass seed was based on minimum weight evaluated for 12 eastern gamagrass populations (data not shown). In addition, ground seed samples of NK603 maize, MON88017 maize and eastern gamagrass were each produced as controls. For marker development and validation, DNA was extracted from ground seed using Qiagen Plant DNeasy kit (Qiagen Inc., Hilden, Germany).

Endpoint TaqMan ${ }^{\circledR}$ PCR was used for detection of the presence of cp4 epsps transgene in eastern gamagrass samples. Endpoint TaqMan ${ }^{\circledR}$ markers were first designed and validated in the Marker Discovery and Development laboratory in Monsanto Co. (St. Louis, MO, USA) and then the methodology was transferred to Eurofins BioDiagnostics Inc. (River Falls, WI, USA) for use in a large-scale screening. To ensure that the marker used in this study was sensitive enough to detect at least one seed containing cp4 epsps transgene in a pool of seeds, nine different primers/ probes combinations specific for cp4 epsps were designed and tested with three different maize internal controls as duplex markers. The DNA probe for $c p 4$ epsps was labeled a $\mathrm{FAM}^{\mathrm{TM}}$ dye, while the DNA internal controls were labeled the $\mathrm{VIC}^{\circledR}$ dye (Applied Biosystems, Waltham, MA, USA). The marker selected for use in large-scale screening consisted of the following components:

- Forward primer, SQ23390, 5'-ACGATTTCGACAGCACCTTCA-3' 
Table 1 Details regarding seed quantity and locations in Illinois, USA where seeds of eastern gamagrass populations (T. dactyloides L.) were collected

\begin{tabular}{|c|c|c|c|c|c|c|}
\hline $\begin{array}{l}\text { Collection } \\
\text { year }\end{array}$ & $\begin{array}{l}\text { Accession } \\
\text { ID }^{\mathrm{a}}\end{array}$ & Longitude & Latitude & $\begin{array}{l}\text { Total number of } \\
\text { collected seed }\end{array}$ & $\begin{array}{l}\text { Seed number for } \\
\text { molecular screen }\end{array}$ & $\begin{array}{l}\text { Seed number for } \\
\text { field screen }\end{array}$ \\
\hline \multirow[t]{26}{*}{2013} & EG 101 & $38^{\circ} 34^{\prime} \mathrm{N}$ & $88^{\circ} 59^{\prime} \mathrm{W}$ & 1143 & 600 & 540 \\
\hline & EG 102 & $38^{\circ} 20^{\prime} \mathrm{N}$ & $89^{\circ} 17^{\prime} \mathrm{W}$ & 1953 & 1000 & 950 \\
\hline & EG 103 & $38^{\circ} 21^{\prime} \mathrm{N}$ & $89^{\circ} 38^{\prime} \mathrm{W}$ & 1373 & 700 & 670 \\
\hline & EG 104 & $38^{\circ} 22^{\prime} \mathrm{N}$ & $89^{\circ} 46^{\prime} \mathrm{W}$ & 1993 & 1000 & 990 \\
\hline & EG 105 & $38^{\circ} 39^{\prime} \mathrm{N}$ & $89^{\circ} 48^{\prime} \mathrm{W}$ & 1543 & 800 & 740 \\
\hline & EG 106 & $38^{\circ} 43^{\prime} \mathrm{N}$ & $89^{\circ} 44^{\prime} \mathrm{W}$ & 1953 & 1000 & 950 \\
\hline & EG 107 & $38^{\circ} 38^{\prime} \mathrm{N}$ & $89^{\circ} 06^{\prime} \mathrm{W}$ & 1183 & 600 & 580 \\
\hline & EG 108 & $38^{\circ} 38^{\prime} \mathrm{N}$ & $89^{\circ} 06^{\prime} \mathrm{W}$ & 1287 & 600 & 580 \\
\hline & EG 109 & $38^{\circ} 40^{\prime} \mathrm{N}$ & $89^{\circ} 06^{\prime} \mathrm{W}$ & 2681 & 1000 & 1000 \\
\hline & EG 110 & $38^{\circ} 45^{\prime} \mathrm{N}$ & $89^{\circ} 05^{\prime} \mathrm{W}$ & 1488 & 700 & 740 \\
\hline & EG 111 & $38^{\circ} 44^{\prime} \mathrm{N}$ & $89^{\circ} 05^{\prime} \mathrm{W}$ & 1208 & 600 & 600 \\
\hline & EG 112 & $38^{\circ} 41^{\prime} \mathrm{N}$ & $89^{\circ} 06^{\prime} \mathrm{W}$ & 1002 & 500 & 500 \\
\hline & EG 113 & $38^{\circ} 38^{\prime} \mathrm{N}$ & $89^{\circ} 06^{\prime} \mathrm{W}$ & 1826 & 900 & 910 \\
\hline & EG 114 & $38^{\circ} 32^{\prime} \mathrm{N}$ & $89^{\circ} 11^{\prime} \mathrm{W}$ & 1405 & 700 & 700 \\
\hline & EG 115 & $38^{\circ} 32^{\prime} \mathrm{N}$ & $89^{\circ} 21^{\prime} \mathrm{W}$ & 1683 & 800 & 840 \\
\hline & EG 116 & $38^{\circ} 32^{\prime} \mathrm{N}$ & $89^{\circ} 24^{\prime} \mathrm{W}$ & 1963 & 1000 & 960 \\
\hline & EG 117 & $38^{\circ} 32^{\prime} \mathrm{N}$ & $89^{\circ} 26^{\prime} \mathrm{W}$ & 2103 & 1000 & 1000 \\
\hline & EG 118 & $38^{\circ} 36^{\prime} \mathrm{N}$ & $89^{\circ} 26^{\prime} \mathrm{W}$ & 1823 & 900 & 910 \\
\hline & EG 119 & $40^{\circ} 05^{\prime} \mathrm{N}$ & $88^{\circ} 13^{\prime} \mathrm{W}$ & 1217 & 600 & 600 \\
\hline & EG 120 & $40^{\circ} 04^{\prime} \mathrm{N}$ & $88^{\circ} 13^{\prime} \mathrm{W}$ & 260 & 100 & 130 \\
\hline & EG 121 & $40^{\circ} 04^{\prime} \mathrm{N}$ & $88^{\circ} 13^{\prime} \mathrm{W}$ & 2286 & 1000 & 1000 \\
\hline & EG 122 & $40^{\circ} 04^{\prime} \mathrm{N}$ & $88^{\circ} 13^{\prime} \mathrm{W}$ & 1163 & 600 & 560 \\
\hline & EG 123 & $40^{\circ} 04^{\prime} \mathrm{N}$ & $88^{\circ} 13^{\prime} \mathrm{W}$ & 1410 & 700 & 700 \\
\hline & EG 124 & $40^{\circ} 08^{\prime} \mathrm{N}$ & $88^{\circ} 22^{\prime} \mathrm{W}$ & 35,000 & 2000 & 3000 \\
\hline & EG 125 & $40^{\circ} 08^{\prime} \mathrm{N}$ & $88^{\circ} 22^{\prime} \mathrm{W}$ & 1882 & 1000 & 800 \\
\hline & EG 126 & $40^{\circ} 08^{\prime} \mathrm{N}$ & $88^{\circ} 23^{\prime} \mathrm{W}$ & 1102 & 500 & 500 \\
\hline Subtotal & & & & 73,930 & 20,900 & 21,450 \\
\hline \multirow[t]{16}{*}{2014} & EG 201 & $38^{\circ} 36^{\prime} \mathrm{N}$ & $89^{\circ} 08^{\prime} \mathrm{W}$ & 2016 & 1000 & 1000 \\
\hline & EG 202 & $38^{\circ} 37^{\prime} \mathrm{N}$ & $89^{\circ} 09^{\prime} \mathrm{W}$ & 2008 & 1000 & 1000 \\
\hline & EG 203 & $38^{\circ} 38^{\prime} \mathrm{N}$ & $89^{\circ} 13^{\prime} \mathrm{W}$ & 2145 & 1000 & 1000 \\
\hline & EG 204 & $38^{\circ} 39^{\prime} \mathrm{N}$ & $89^{\circ} 15^{\prime} \mathrm{W}$ & 2031 & 1000 & 1000 \\
\hline & EG 205 & $38^{\circ} 40^{\prime} \mathrm{N}$ & $89^{\circ} 13^{\prime} \mathrm{W}$ & 2011 & 1000 & 1000 \\
\hline & EG 206 & $38^{\circ} 45^{\prime} \mathrm{N}$ & $89^{\circ} 11^{\prime} \mathrm{W}$ & 2074 & 1000 & 1000 \\
\hline & EG 207 & $38^{\circ} 47^{\prime} \mathrm{N}$ & $89^{\circ} 09^{\prime} \mathrm{W}$ & 2007 & 1000 & 1000 \\
\hline & EG 208 & $38^{\circ} 56^{\prime} \mathrm{N}$ & $89^{\circ} 05^{\prime} \mathrm{W}$ & 2214 & 1000 & 1000 \\
\hline & EG 209 & $38^{\circ} 38^{\prime} \mathrm{N}$ & $89^{\circ} 06^{\prime} \mathrm{W}$ & 2361 & 1000 & 1000 \\
\hline & EG 210 & $38^{\circ} 30^{\prime} \mathrm{N}$ & $89^{\circ} 06^{\prime} \mathrm{W}$ & 2140 & 1000 & 1000 \\
\hline & EG 211 & $38^{\circ} 32^{\prime} \mathrm{N}$ & $89^{\circ} 21^{\prime} \mathrm{W}$ & 2081 & 1000 & 1000 \\
\hline & EG 212 & $38^{\circ} 32^{\prime} \mathrm{N}$ & $89^{\circ} 21^{\prime} \mathrm{W}$ & 2150 & 1000 & 1000 \\
\hline & EG 213 & $38^{\circ} 32^{\prime} \mathrm{N}$ & $89^{\circ} 23^{\prime} \mathrm{W}$ & 2207 & 1000 & 1000 \\
\hline & EG 214 & $38^{\circ} 32^{\prime} \mathrm{N}$ & $89^{\circ} 26^{\prime} \mathrm{W}$ & 2182 & 1000 & 1000 \\
\hline & EG 215 & $38^{\circ} 35^{\prime} \mathrm{N}$ & $89^{\circ} 23^{\prime} \mathrm{W}$ & 2014 & 1000 & 1000 \\
\hline & EG 216 & $38^{\circ} 38^{\prime} \mathrm{N}$ & $89^{\circ} 22^{\prime} \mathrm{W}$ & 2413 & 1000 & 1000 \\
\hline
\end{tabular}


Table 1 continued

\begin{tabular}{|c|c|c|c|c|c|c|}
\hline $\begin{array}{l}\text { Collection } \\
\text { year }\end{array}$ & $\begin{array}{l}\text { Accession } \\
\text { ID }^{\mathrm{a}}\end{array}$ & Longitude & Latitude & $\begin{array}{l}\text { Total number of } \\
\text { collected seed }\end{array}$ & $\begin{array}{l}\text { Seed number for } \\
\text { molecular screen }\end{array}$ & $\begin{array}{l}\text { Seed number for } \\
\text { field screen }\end{array}$ \\
\hline & EG 217 & $38^{\circ} 66^{\prime} \mathrm{N}$ & $90^{\circ} 17^{\prime} \mathrm{W}$ & 616 & 300 & 133 \\
\hline & EG 218 & $38^{\circ} 76^{\prime} \mathrm{N}$ & $89^{\circ} 81^{\prime} \mathrm{W}$ & 1663 & 800 & 429 \\
\hline & EG 219 & $38^{\circ} 73^{\prime} \mathrm{N}$ & $89^{\circ} 37^{\prime} \mathrm{W}$ & 1968 & 1000 & 445 \\
\hline & EG 220 & $38^{\circ} 55^{\prime} \mathrm{N}$ & $89^{\circ} 33^{\prime} \mathrm{W}$ & 2108 & 1000 & 573 \\
\hline & EG 221 & $38^{\circ} 75^{\prime} \mathrm{N}$ & $89^{\circ} 91^{\prime} \mathrm{W}$ & 2751 & 1000 & 1000 \\
\hline & EG 222 & $38^{\circ} 72^{\prime} \mathrm{N}$ & $89^{\circ} 91^{\prime} \mathrm{W}$ & 2766 & 1000 & 1000 \\
\hline & EG 223 & $38^{\circ} 67^{\prime} \mathrm{N}$ & $90^{\circ} 07^{\prime} \mathrm{W}$ & 2969 & 1000 & 1000 \\
\hline & EG 224 & $38^{\circ} 62^{\prime} \mathrm{N}$ & $89^{\circ} 38^{\prime} \mathrm{W}$ & 3009 & 1000 & 1000 \\
\hline & EG 225 & $38^{\circ} 76^{\prime} \mathrm{N}$ & $89^{\circ} 86^{\prime} \mathrm{W}$ & 3097 & 1000 & 1000 \\
\hline & EG 226 & $38^{\circ} 59^{\prime} \mathrm{N}$ & $89^{\circ} 37^{\prime} \mathrm{W}$ & 3108 & 1000 & 1000 \\
\hline & EG 227 & $38^{\circ} 75^{\prime} \mathrm{N}$ & $89^{\circ} 91^{\prime} \mathrm{W}$ & 3936 & 1000 & 1000 \\
\hline & EG 228 & $38^{\circ} 53^{\prime} \mathrm{N}$ & $89^{\circ} 35^{\prime} \mathrm{W}$ & 4362 & 1000 & 613 \\
\hline Subtotal & & & & 66,407 & 27,100 & 25,193 \\
\hline Total & & & & 140,337 & 48,000 & 46,643 \\
\hline
\end{tabular}

${ }^{\text {a }}$ EG 101- EG 228 were designations for 54 eastern gamagrass populations

- Reverse primer, SQ23391, 5'-GTCACCGTCTT CCGATTTCAC- $3^{\prime}$

- Probe, PB50320, 5'-6FAM-TCGGCGACGCCT $\mathrm{C}-3^{\prime}-\mathrm{MGB}$

- Internal control forward primer, SQ1241, 5'GCCTGCCGCAGACCAA-3'

- Internal control reverse primer, SQ1242, 5'CAATGCAGAGCTCAGCTTCATC-3'

- Internal control probe, PB50323, 5'-VIC-TCCAGTACGTGCAGTCCCTCCTCCCT-3'-TAMRA.

A maize internal control was used that targeted the bnlg1079 locus (Andorf et al. 2010), The control was maize specific and was not cross-amplified in eastern gamagrass. Samples containing cp4 epsps were designated as positive, and those not containing the transgene were designated as negative. This TaqMan ${ }^{\circledR}$ assay was able to distinguish the three clusters for (1) eastern gamagrass, (2) maize control without the $c p 4$ epsps transgene, and (3) maize samples with the $c p 4$ epsps transgene (Fig. 1). The TaqMan ${ }^{\circledR}$ assay was able to detect the cp4 epsps transgene in both NK603 and MON88017.

An eastern gamagrass marker was developed for use as a control to assure that the eastern gamagrass DNA samples used in this study were assayable. The eastern gamagrass marker detects a single copy EST sequence, GenBank Accession AY789601 (FL2 gene), and also detects maize DNA due to sequence homology between these two species. The FL2 gene marker allowed for the same marker to be used as an internal standard to confirm DNA extraction quality for both eastern gamagrass samples and maize control samples. The eastern gamagrass marker was comprised of:

- Forward primer, SQ50935, 5'-GAGGAGGAAGAAGGAGCTGAGG-3'

- Reverse primer, SQ50936, 5'-CCTCGTCTCC GTCGTTCGT-3'

- Probe, PB50321, 5'-TGGACGTGCTGGACGA$3^{\prime}$.

Genotyping for marker development was done in a $5 \mu \mathrm{l}$ reaction consisting of $2.5 \mu \mathrm{l}$ GTXpress master mix (Applied Biosystems, Waltham, MA, USA), $0.02 \mu \mathrm{l}$ each of the four primers at $100 \mu \mathrm{M}$ concentration, $0.01 \mu \mathrm{l}$ each of the two probes at $100 \mu \mathrm{M}, 4$ ng template DNA plus water to make up $5 \mu \mathrm{l}$. The PCR assay was carried on a GeneAmp PCR System 9700 Thermal Cycler (Applied Biosystems, Waltham, MA, USA) with the following temperature profile: $95^{\circ} \mathrm{C}$ for $20 \mathrm{~s}$; 35 cycles of $95{ }^{\circ} \mathrm{C}$ for $3 \mathrm{~s}$ and $60{ }^{\circ} \mathrm{C}$ for $20 \mathrm{~s}$, and hold at $10{ }^{\circ} \mathrm{C}$. The GTXpress master mix contains a ROX internal standard dye used to normalize each assay. The plate was read on a Tecan Safire Microplate reader (Tecan Group, Ltd., Männedorf, Switzerland). 


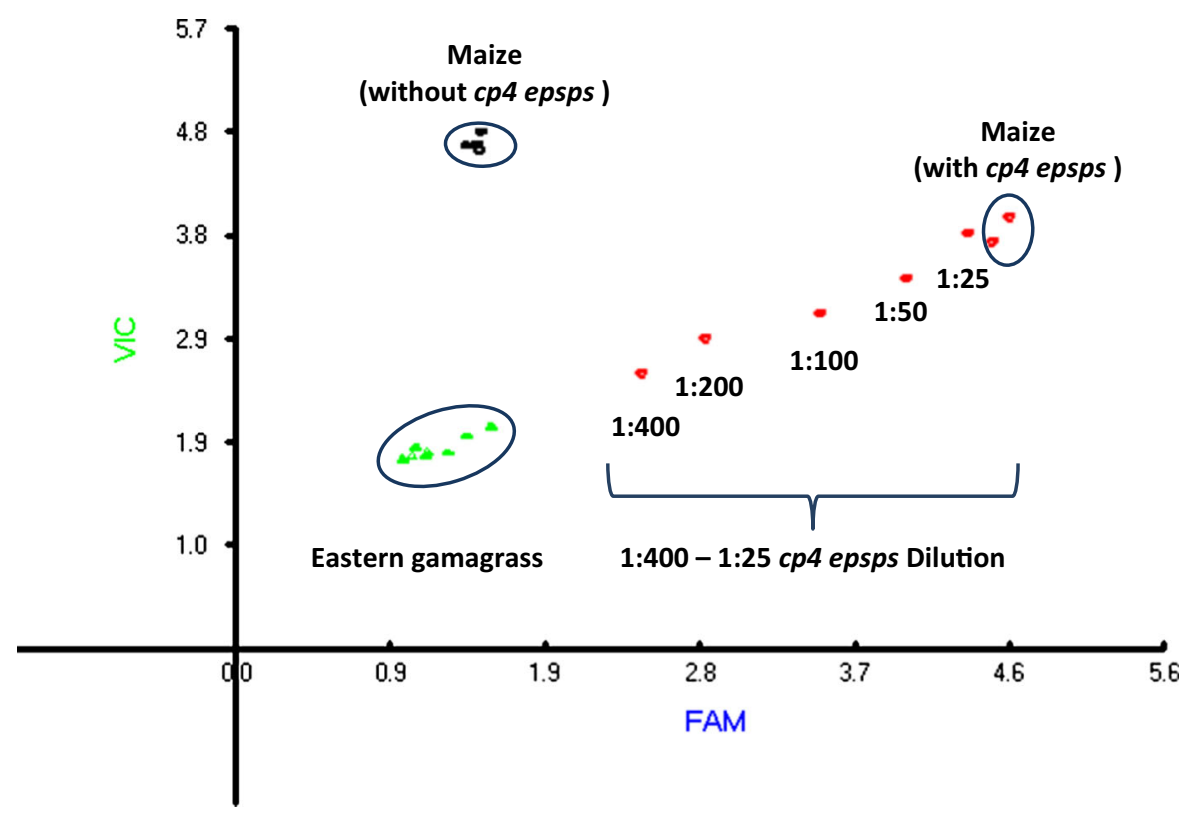

Fig. 1 Genotyping plot for CP4 EPSPS trait using Endpoint TaqMan ${ }^{\circledR}$ PCR method (cp4 epsps marker with maize internal control). VIC and FAM represent the signal intensity ratios of each dye to a ROX dye standard added to each reaction. VIC dye-labeled DNA probe identifies the maize internal standard

A validation test was performed at Eurofins BioDiagnostics, Inc. (River Falls, WI, USA) to confirm that the laboratory was proficient to conduct the assay at their facility. A 96-well validation plate was prepared by Monsanto that contained 40 ground samples of 1:50 ratio of maize with MON88017 in eastern gamagrass and 40 samples of an eastern gamagrass control. The samples were randomized in a single blind study (blind to Eurofins BioDiagnostics). The results showed $0 \%$ false positive and $0 \%$ false negative readings, which was sufficient to deem the Eurofins BioDiagnostics laboratory proficient to run the assay on 50 seed pools of eastern gamagrass.

\section{Molecular screen}

For screening the collected eastern gamagrass populations for presence of CP4 EPSPS trait, on average 18 samples of 50 seeds each were prepared for each population and subjected to molecular assays. Each 50 -seed sample was ground with dry ice, and stored at $-80{ }^{\circ} \mathrm{C}$ until analysis. A total of 960 samples (48,000 seeds) from 54 populations were tested. Genomic DNA was extracted from 6 to $9 \mathrm{mg}$ of each gene and FAM identifies the cp4 epsps transgene (NK603 product). The figure does not contain a control without the DNA template, as it was not needed in this method development experiment

50 -seed pooled sample using the BDI Prime ${ }^{\mathrm{TM}}$ DNA extraction method. This method was developed at Eurofins BioDiagniostics as a commercially available service, using a silica filter based DNA extraction. The BDI Prime ${ }^{\mathrm{TM}}$ DNA extraction was developed based on the protocol described by Whitlock et al. (2008) with some modifications. Each 50-seed sample was subjected to amplification in $10 \mu \mathrm{l} \mathrm{PCR}$ reactions consisting of $5 \mu \mathrm{l}$ Perfecta Custom Genotyping Toughmix master mix (Quanta Biosciences, Inc., Beverly, MA, USA), $0.1 \mu \mathrm{l}$ each of the two CP4 EPSPS product primers at $100 \mu \mathrm{M}$ concentration, $0.02 \mu \mathrm{l}$ of the event probe at $100 \mu \mathrm{M}$, 12 ng template DNA plus proper amount of water to make up $10 \mu \mathrm{l}$. The endogenous reference assay was run as a separate assay using the same quantities as the cp4 epsps assay. Endpoint TaqMan ${ }^{\circledR}$ PCR was performed on an ABI Veriti PCR Thermal Cycler (Thermo Fisher Scientific, Foster City, CA, USA) with the following temperature profile: $95{ }^{\circ} \mathrm{C}$ for $30 \mathrm{~s} ; 35$ cycles of $95{ }^{\circ} \mathrm{C}$ for $3 \mathrm{~s}$ and $60{ }^{\circ} \mathrm{C}$ for $20 \mathrm{~s}$. The plate was read on a Molecular Devices Gemini XPS Microplate reader (Molecular Devices, Sunnyvale, CA, USA). 
Assessment of interspecific hybridization

between maize and eastern gamagrass

\section{Plant material}

To make interspecific hybrids by hand-pollination in the greenhouse, rhizomes were collected from an eastern gamagrass field nursery at the University of Illinois at Urbana-Champaign in 2014 and 2015 from population EG 124. After a killing frost, eastern gamagrass rhizomes were unearthed and stored at $4{ }^{\circ} \mathrm{C}$ in a cold room. Eastern gamagrass rhizomes were transplanted into pots in the greenhouse. Since diploid eastern gamagrass has higher chances of sexual reproduction compared to a tetraploid cytotype, the ploidy level of the rhizomes was determined by flow cytometric analysis and confirmed by chromosome count.

\section{Ploidy confirmation}

Nuclear DNA content determination was conducted using a procedure slightly modified from Rayburn et al. (2005). Briefly, $2.5 \mathrm{~cm}$ of fresh young stems from eastern gamagrass and maize (used as an internal control), were co-homogenized and placed in a $20-\mathrm{ml}$ beaker containing $10 \mathrm{ml}$ extraction buffer and $200 \mu \mathrm{l}$ $25 \%$ Triton X. The extraction buffer was composed of $13 \% \mathrm{v} / \mathrm{v}$ hexylene glycol, $10 \mathrm{mM}$ Tris- $\mathrm{HCl}$, and $10 \mathrm{mM} \mathrm{MgCl}_{2}$. The nuclear DNA content of the maize was calibrated at $5.14 \mathrm{pg}$ using sorghum hybrid $84 \mathrm{G} 62$ with $1.74 \mathrm{pg} / 2 \mathrm{C}$ nuclei (Rayburn et al. 2005). The tissue was homogenized using a tissue grinder for $20 \mathrm{~s}$ at $4500 \mathrm{rpm}$, and the samples were filtered through a $50 \mathrm{~nm}$ filter into a test tube and maintained on ice. Following filtration, samples were centrifuged for $20 \mathrm{~min}$ at $2000 \mathrm{rpm}$ at $4{ }^{\circ} \mathrm{C}$. The supernatant was removed, and nuclei were re-suspended in $300 \mu \mathrm{l}$ of PI stain $\left(3 \% \mathrm{w} / \mathrm{w}\right.$ polyethylene glycol $6000,50 \mu \mathrm{g} \mathrm{ml}^{-1}$ PI, $180 \mathrm{U} \mathrm{ml}^{-1}$ RNase, $0.1 \%$ Triton X-100 in $4 \mathrm{mM}$ citrate buffer). The solution was transferred to a $1.5-\mathrm{ml}$ conical tube and incubated for $20 \mathrm{~min}$ at $37^{\circ} \mathrm{C}$. Following incubation, $300 \mu \mathrm{l}$ of PI salt (3\% PEG, $50 \mu \mathrm{g} \mathrm{ml}^{-1} \mathrm{PI}, 0.1 \%$ Triton $\mathrm{X}-100$ in $400 \mathrm{mM} \mathrm{NaCl}$ ) was added to each sample. Samples were then briefly vortexed, placed on ice, and stored at $4{ }^{\circ} \mathrm{C}$ for at least $1 \mathrm{~h}$. The analysis of relative DNA content was conducted with BD LSR flow cytometry (BD Biosciences, San Jose, CA, USA) equipped with a excitation wavelength of $488 \mathrm{~nm}$ and a 680/45 filter in the Flow Cytometry Laboratory (Biotechnology Center, University of Illinois at Urbana-Champaign, USA). Approximately 30,000 nuclei per sample were analyzed. The relative DNA content was estimated using the relative fluorescence of the sample divided by the relative fluorescence of the standard.

To confirm ploidy levels by chromosome count, actively growing root tips (about $2 \mathrm{~cm}$ in length) were collected from eastern gamagrass plants used for nuclear DNA content determination. Chromosome preparation was conducted according to Kim et al. (2010). The root tips, which were collected from plants transplanted into pots and maintained in the greenhouse, were pretreated with $20 \mathrm{ml}$ of $0.05 \%$ 8-hydroxyquinoline for three hours and fixed at room temperature for at least one day in a 3:1 ratio of ethanol to acetic acid. The fixed root tips were rinsed in double distilled $\mathrm{H}_{2} \mathrm{O}$, hydrolyzed in $5 \mathrm{~N} \mathrm{HCl}$ for $45 \mathrm{~min}$, and stained with Feulgen's reagent for two hours. The root tips were then rinsed again with double distilled $\mathrm{H}_{2} \mathrm{O}$ and soaked in an enzyme solution ( $0.2 \mathrm{~g}$ Cellulysin and $0.1 \mathrm{~g}$ Macerase in $10 \mathrm{ml}$ of $10 \mathrm{mM}$ EDTA) for two hours. One drop of acetic acid was added to the root tips before squashing. A cover slide was placed over the tissue and then squashed with thumb pressure. The cells were imaged with a microscope at $60 \mathrm{x}$ magnification (Olympus BX61, Olympus Scientific Solutions Americas Corporation, Waltham, MA, USA) and photographed with a digital camera (Olympus U-CMAD3).

\section{Interspecific and intraspecific pollinations}

For the greenhouse experiment, a total of 20 and 32 diploid eastern gamagrass plants were used as female parents in 2014 and 2015, respectively. Maize plants homozygous for glyphosate-tolerant CP4 EPSPS trait (NK603) were used as male parents. To synchronize the flowering time of the two species, maize was planted at weekly intervals between June and November in 2014 and between March and July in 2015. When eastern gamagrass spikes emerged (and prior to pollen shed) the male portion of the flower was removed and the female portion was covered with a pollination bag. At anthesis, maize pollen was transferred to the stigmas of eastern gamagrass. The pollinated gamagrass spikes were then covered again 
with an isolation bag to protect against uncontrolled pollination (S-Fig. 1).

Hand pollination was performed within each species (i.e., eastern gamagrass and maize) as a control to test the success of the pollination procedure in each year. For eastern gamagrass, pollen from one eastern gamagrass plant was used to pollinate stigmas of another plant (sib-pollination). For maize, ears were bagged prior to silking, and tassels were bagged at anthesis the day before self-pollination was conducted.

Eastern gamagrass spikelets were harvested at maturity and each individual spikelet was examined for the presence of the seed. Every identified seed was tested for germination. Tissues from resulting seedlings and from the seed that failed to germinate were tested for the presence of cp4 epsps. The testing was conducted using QuickStix ${ }^{\mathrm{TM}}$ Strips for cp4 epsps Leaf and Seed (Envirologix Inc., Portland, MN, USA) for detection of the transgenic protein, as well as Endpoint TaqMan ${ }^{\circledR}$ PCR assay described earlier for detection of the transgene.

\section{Results and discussion}

Assessment of gene flow from glyphosate-tolerant maize to eastern gamagrass

A total of 140,337 seeds representing 54 eastern gamagrass populations were collected from 43 diverse Illinois locations where it grows naturally in close proximity of maize fields (Table 1). The zygosity was not determined for these populations, with the exception of the EG 124 population which was comprised of both diploid and tetraploid individuals. This is not unexpected as observations from Newell and de Wet (1974) indicated that majority of eastern gamagrass in Illinois and the neighboring states is diploid $(2 \mathrm{n}=36)$ or tetraploid $(2 n=72)$. They also demonstrated that phenotypic characteristics alone cannot be predictive of ploidy levels, even though tetraploid populations generally tend to be slightly more robust than diploid ones. Based on these observations it can be assumed that the populations utilized in the present study were comprised of diploid, tetraploid or a mixture of diploid and tetraploid individuals.

A total of 94,643 eastern gamagrass seeds were used in this study to test for either glyphosate- tolerance in the field screen or to evaluate for the presence of the cp4 epsps transgene in the molecular screen. The large sample size and different approaches were utilized to increase the probability of finding potential interspecific hybrids even if they occur at a very low frequency.

\section{Presencelabsence of glyphosate-tolerance in field screen}

On average, 864 seeds from each of 54 eastern gamagrass populations were evaluated over a 2-year period in the field experiment (S-Fig. 2). Specifically, 21,450 seeds collected from 26 natural eastern gamagrass populations and 25,193 seeds collected from 28 natural populations were planted on the University of Illinois Research Farm in 2014 and 2015, respectively. Emergence rate averaged across populations was $45.2 \%$ in 2014 and $11.3 \%$ in 2015 . A total of 12,524 emerged seedlings across both years were treated with the glyphosate herbicide. No seedlings survived the herbicide treatment (Table 2), which indicated a lack of glyphosate-tolerance across these diverse natural populations of eastern gamagrass. The absence of glyphosate-tolerance suggests a lack of interspecific hybridization between maize and eastern gamagrass even though these eastern gamagrass populations grew near commercial maize fields and were exposed to transgenic maize pollen for years.

Presencelabsence of cp 4 epsps transgene in molecular screen

In order to evaluate a large number of eastern gamagrass seeds for the presence of the cp4 epsps transgene, method was developed to assess the sensitivity of a genotyping assay with regards to the number of seeds that can be bulked together. Results of the genotyping assay indicated that the assay is sensitive to reliably detect cp4 epsps in one out of 200 bulked seeds (Fig. 1). Thus, the decision to evaluate bulks of 50 seed in this study provided even higher assay sensitivity and additional certainty of detecting a very small cp4 epsps presence.

A total of 48,000 seeds from 54 populations of eastern gamagrass were tested for the presence/ absence of cp4 epsps transgene. The genotyping was conducted on 960 samples of 50-seed pools. Each sample indicated the absence of glyphosate-tolerance 
Table 2 Field screen: mortality (\%) of eastern gamagrass plants after glyphosate application

\begin{tabular}{lllll}
\hline Year & Populations & Number of planted seeds & Number of emerged seedlings & Mortality $(\%)$ \\
\hline 2014 & 26 & 21,450 & 9687 & 100 \\
2015 & 28 & 25,193 & 2837 & 100 \\
Total & 54 & 46,643 & 12,524 & 100 \\
\hline
\end{tabular}

cp4 epsps transgene. Initial testing showed that two out of 960 samples had an uncallable reading. These two samples were shipped to the Marker Discovery and Development laboratory at Monsanto for further investigation. Using the Endpoint TaqMan ${ }^{\circledR}$ method these samples were found to be negative for cp4 epsps. A follow up experiment using real-time PCR was conducted, and the results indicated that the CP4 EPSPS signal was below the 1:400 control samples which was consistent with a very low level contaminant or non-specific amplification. These results indicated that all 48,000 tested seeds, representing 54 eastern gamagrass populations collected from 43 locations, showed an absence of cp4 epsps transgene (Table 3).

Taken together, our results from the field screening and molecular genotyping show that no gene flow occurred from transgenic maize to eastern gamagrass even though the evaluated populations of eastern gamagrass have been exposed to CP4 EPSPS maize pollen over a 15-year period. These results are in agreement with observations from others researchers regarding limitations associated with outcrossing between maize and eastern gamagrass. First, experimental hybrids between maize and Tripsacum have only been obtained utilizing specific greenhouse and laboratory techniques (Mangelsdorf and Reeves 1931; Beadle 1980; Bernard and Jewell 1985; Randolph 1970; James 1979). Secondly, natural interspecific hybrids between maize and the Tripsacum genus have not been reported, even though Tripsacum grows in close proximity to millions of hectares of maize in the USA Corn Belt (Beadle 1980; Randolph 1970;
Mangelsdorf and Reeves 1931). Talbert et al. (1990) conducted a cytogenetic study that showed that transposable elements ( $M u$ and Spm) found in maize were absent from eastern gamagrass which provided additional evidence of lack of ongoing gene flow between the two species. Furthermore, no evidence exists of ongoing natural introgression between maize and the genus Tripsacum in South America (de Wet et al. 1972). Thirdly, lack of observed hybrids in nature is not surprising considering the complete male sterility observed in experimental hybrids (Beadle 1980; Randolph 1959; Talbert et al. 1990) and the genetic incompatibility between Tripsacum and maize due to irregular chromosome pairing (Beadle 1980).

Assessment of interspecific hybridization between maize and eastern gamagrass

To further assess the possibility of hybridization and the production of viable offspring between maize and eastern gamagrass, hand cross-pollination attempts were conducted in greenhouse. Considering that diploid cytotype of eastern gamagrass reproduced sexually like maize, it was important to verify that the attempted cross-pollination was conducted with diploid rather than tetraploid eastern gamagrass plants whose reproduction is based on facultative apomixes. To minimize assessing asexually formed seeds, it was necessary to confirm the ploidy level of all eastern gamagrass plants used in the greenhouse experiment. Flow cytometric analysis confirmed that all eastern gamagrass plants used in attempted cross-pollination experiment were diploid (S-Fig. 3). The ploidy level

Table 3 Molecular screen: absence of cp4 epsps transgene in eastern gamagrass seeds

\begin{tabular}{lllll}
\hline Collection years & Populations & Number of tested seeds & Number of samples & cp4 epsps detection (\%) \\
\hline $2013 / 2014$ & 54 & 48,000 & 960 & 0 \\
\hline
\end{tabular}


determined by flow cytometric analysis was confirmed with chromosome counts. As expected for diploid cytotype, all eastern gamagrass plants used for attempted cross-pollination with maize had 36 chromosomes (S-Fig. 4).

Across the 2 years, 139 cross-pollinations were attempted between eastern gamagrass and maize (Table 4). Each eastern gamagrass inflorescence was composed of 1-3 spikes and produced 5-23 spikelets. In 2014, a total of 58 cross-pollinations were attempted. Among the 662 spikelets obtained, only 26 contained seed (all from different inflorescences). The 26 seeds were subjected to germination, but only 4 seedlings were obtained, while 22 of them did not germinate. Tissues from all 26 individuals (4 seedlings and 22 non-germinated seeds) were tested for the presence of the glyphosate-tolerant trait and all indicated absence of cp4 epsps transgene. Furthermore, there was no difference in genome size between maternal parent (eastern gamagrass) and the four seedlings, indicating lack of cross-pollination with maize.

In 2015, a total of 81 cross-pollinations were attempted. Among the 867 spikelets obtained, only one seed was formed, but it did not germinate. In contrast, sib-pollinated eastern gamagrass resulted in high number of seeds as pollination rate was over $80 \%$ across both years (Table 4). This confirmed selfcompatibility of eastern gamagrass and appropriateness of pollination techniques used in this study.

These 27 seeds harvested from eastern gamagrass plants across 2 years could not have resulted from outcrossing with maize, as cp4 epsps transgene from maize pollen was absent. These seeds could have been developed parthenogenetically, which has been observed with diploid eastern gamagrass when fertilization was absent (de Wet 1991). Alternatively, these seeds resulted from accidental, unintended self-pollination. Even though attempts were made to remove male portions of the spikes (S-Fig. 1), some male spikelets on the distal end of the female flower might have been overlooked resulting in a few self-pollinations. More seeds were observed in 2014 with fewer pollination attempts than in 2015 (26 and 1, respectively). In 2015, to further eliminate the possibility of self-pollination, the male inflorescence structures and the distal end of female flower structure were removed from the spikes, which resulted in much lower parthenogenetic/self-pollinated seed number. In summary, across both years, a total of 1529 spikelets were collected, but most were barren as only 27 seeds were formed. None of the seeds resulted from crosspollination with maize. Even under conditions that favor outcrossing, eastern gamagrass used as female parent did not hybridize with maize. This is in agreement with Mangelsdorf and Reeves (1939) and Randolph (1970) who reported that they were not able to obtain viable seeds by pollinating diploid Tripsacum with maize pollen.

To our knowledge this is the first study to evaluate directly the potential of pollen-mediated gene flow from transgenic maize to natural populations of eastern gamagrass. No evidence of gene flow from transgenic maize to eastern gamagrass in nature was observed even though the two species have grown in close proximity for years and have had ample

Table 4 Greenhouse experiment: Success of interspecific pollination $\left(\mathrm{EG}^{\mathrm{a}} \times\right.$ Maize) compared to intraspecific pollination $(\mathrm{EG} \times \mathrm{EG})$

\begin{tabular}{llllcll}
\hline Year & $\begin{array}{l}\text { Pollination } \\
\text { type }\end{array}$ & $\begin{array}{l}\text { Number of pollination } \\
\text { attempts }\end{array}$ & $\begin{array}{l}\text { Number of } \\
\text { spikelets }\end{array}$ & $\begin{array}{l}\text { Number of } \\
\text { seeds }\end{array}$ & $\begin{array}{l}\text { Number of spikelets per } \\
\text { inflorescence }\end{array}$ & $\begin{array}{l}\text { Pollination rate } \\
(\%)^{\mathrm{c}}\end{array}$ \\
\hline 2014 & EG $\times$ EG & 10 & 102 & 83 & 10.2 & 81.4 \\
& EG $\times$ Maize & 58 & 662 & 26 & 11.4 & $3.9(0.0)$ \\
2015 & EG $\times$ EG & 10 & 108 & 86 & 10.8 & 77.8 \\
& EG $\times$ Maize & 81 & 867 & 1 & 10.7 & $0.1(0.0)$ \\
Total & EG $\times$ EG & 20 & 210 & 169 & 10.5 & 80.5 \\
& EG $\times$ Maize & 139 & 1529 & 27 & 11.0 & $1.8(0.0)$ \\
\hline
\end{tabular}

${ }^{\mathrm{a}} \mathrm{EG}=$ eastern gamagrass used as maternal parent

b A total number of spikelets that were exposed to maize pollen $(E G \times$ Maize) or eastern gamagrass pollen $(E G \times E G)$

c Pollination rate is expressed as percentage of spikelets with seeds. The number in parenthesis indicates the percentage of EG $\times$ Maize cross-pollinations 
opportunities for outcrossing. These results should be taken in consideration when the Agreement of Maize Center of Origin in Mexico is updated as part of environmental risk assessment regarding the potential for pollen-mediate gene flow from transgenic maize to its wild relatives.

Acknowledgements The authors are grateful to Daniel L. Kendrick, Roger J. Effertz, Sonya J. Franklin and Timothy K. Ball for reviewing the manuscript. Funding was provided by Monsanto Fund (Grant Nos. PLC-2014-0524, PLC-2014-0526).

Open Access This article is distributed under the terms of the Creative Commons Attribution 4.0 International License (http:// creativecommons.org/licenses/by/4.0/), which permits unrestricted use, distribution, and reproduction in any medium, provided you give appropriate credit to the original author(s) and the source, provide a link to the Creative Commons license, and indicate if changes were made.

\section{References}

Andorf CM, Lawrence CJ, Harper LC, Schaeffer ML, Campbell DA, Sen TZ (2010) The locus lookup tool at MaizeGDB: identification of genomic regions in maize by integrating sequence information with physical and genetic maps. Bioinformatics 26:434-436

Beadle G (1980) The ancestry of corn. Sci Am 242:112-119

Belova IV, Tarakanova TK, Abdyrahmanova EA, Sokolov VA, Panikhin PA (2010) Chromosome control of apomixis in maize-gamagrass hybrids. Russ J Genet 46(9):1055-1057

Bernard S, Jewell DC (1985) Crossing maize with sorghum, Tripsacum and millet: the productions and their level of development following pollination. Theor Appl Genet 70:474-483

Blakey CA, Costich D, Sokolov V, Islam-Faraidi MN (2007) Tripsacum genetics: from observations along a river to molecular genetics. Maydica 52:81-99

Burson BL, Voigt PW, Sherman RA, Dewald CL (1990) Apomixis and sexuality in eastern gamagrass. Crop Sci 30:86-89

Collins GN, Kempton JH (1914) A hybrid between Tripsacum and Euchleane. J Wash Acad Sci 4:114-117

Collins GN, Kempton JH (1916) Patrogenesis. J Hered 7:106-118

de Wet JMJ (1991) Cytogenetics of Zea and Tripsacum. In: Gupta PK, Tsuchiya T (eds) Chromosome engineering in plants: genetics, breeding, evolution, part A. Elsevier, Amsterdam, pp 483-492

de Wet JMJ, Harlan JR (1972) Origin of maize: the tripartite hypothesis. Euphytica 21:271-279

de Wet JMJ, Harlan JR (1974) Tripsacum-maize interaction: a novel cytogenetic system. Genetics 78:493-502

de Wet JMJ, Harlan JR (1978) Tripsacum and the origin of maize. In: Walden DB (ed) Maize breeding and genetics. Wiley, New York, pp 129-141 de Wet JMJ, Harlan JR, Lambert RJ, Engle LM (1972) Introgression from Tripsacum into Zea and the origin of maize. Caryologia 25:25-31

de Wet JMJ, Timothy DH, Hilu KW, Fletcher GB (1981) Systematics of South American Tripsacum (Gramineae). Am J Bot 68:269-276

de Wet JMJ, Harlan JR, Brink DE (1982) Systematics of Tripsacum dactyloides (Gramineae). Am J Bot 69:1251-1257

de Wet JMJ, Newell CA, Brink DE (1984) Counterfeit hybrids between Tripsacum and Zea (Gramineae). Am J Bot 71:245-251

Dewald CL, Kindiger B (1994) Genetic transfer of gynomonoecy from diploid to triploid eastern gamagrass. Crop Sci 34:1259-1262

Doebley JF (1983) The taxonomy and Evolution of Tripsacum and teosinte, the closest relatives of maize. In: Proceedings of international maize virus disease colloquium and workshop, The Ohio State University, Wooster, OH, pp 15-28

Dresselhaus T, Lausser A, Marton ML (2011) Using maize as a model to study pollen tube growth and guidance, crossincompatibility and sperm delivery in grasses. Ann Bot 108:727-737

Duvick SA, Pollak LM, Edwards JW, White PJ (2006) Altering the fatty acid composition of Corn Belt corn through Tripsacum introgression. Maydica 51:409-416

Ellstrand NC (2001) Why transgenes wander, should we worry? Plant Physiol 125:1543-1545

Eubanks MW (1994) Methods and materials for conferring Tripsacum genes in maize. United States Patent 5,330,547

Farquharson LI (1955) Apomixis and polyembryony in Tripsacum dactyloides. Am J Bot 1:737-743

Farquharson LI (1957) Hybridization of Tripsacum and Zea. J Hered 48:295-299

Fernandez-Cornejo J, Wechsler S, Livingston M, Mitchell L (2014) Genetically engineered crops in the United States. USDA-ERS Econ Res Rep 1:162

Gewin V (2003) Genetically modified corn-environmental benefits and risks. PLoS Biol 1(1):e8. doi:10.1371/journal/ pbio.0000008

ISAAA, GM Approval Database (2016). http://www.isaaa.org/ gmapprovaldatabase/default.asp. Accessed 28 Aug 2016

Graminelli D, Leblanc O, Espinosa E, Perotti E, Gonzales de Leon D, Savidan Y (1996) Non-Mendelian transmission of apomixis in mazie-Tripsacum hybrids caused by a transmission ratio distortion. Heredity 80:40-47

Gurney AL, Grimanelli D, Kanampiu F, Hoisington D, Scholes JD, Press MC (2003) Novel sources of resistance to Striga hermonthica in Tripsacum dactyloides, a wild relative of maize. New Phytol 160:557-568

Hajjar R, Hodgkin T (2007) The use of wild relatives in crop improvement: a survey of developments over the last 20 years. Euphytica 156:1-13

James J (1979) New Maize $\times$ Tripsacum Hybrids for Maize Improvement. Euphytica 28:239-247

James C (2015) 20th anniversary (1996 to 2015) of the global commercialization of biotech crops and biotech crop highlights in 2015. ISAAA Brief No. 51, ISAAA, Ithaca, NY, USA

Kim S, Rayburn AL, Lee DK (2010) Genome size and chromosome analyses in prairie cordgrass. Crop Sci 50:2277-2282 
Kindiger B, Dewald CL (1997) The reproductive versatility of eastern gamagrass. Crop Sci 37:1351-1360

Leblanc O, Grimanelli D, Gonzalez-de-Leon D, Savidan Y (1995) Detection of the apomictic mode of reproduction in maize-Tripsacum hybrids using maize RFLP markers. Theor Appl Genet 90:1198-1203

Li YG, Dewald CL, Sims PL (1999) Genetic relationships within Tripsacum as detected by RAPD variation. Ann Bot 84:695-702

Mangelsdorf PC, Reeves RG (1931) Hybridization of maize, Tripsacum, and Euchlaena. J Hered 22:329-343

Mangelsdorf PC, Reeves RG (1939) The origin of Indian corn and its relatives. Texas agricultural experiment station bulletin No. 574

Newell CA, de Wet JM (1974) Morphological and cytological variability in Tripsacum dactyloides (Gramineae). Am J Bot 1:652-664

Randolph LF (1959) The origin of maize. Indian J Genet Plant Breed 19:1-12

Randolph LF (1970) Variation among Tripsacum populations of Mexico and Guatemala. Brittonia 22:305-337

Raybould AF, Gray AJ (1993) Genetically modified crops and their wild relatives: a UK perspective. J Appl Ecol 30:199-219

Rayburn AL, McCloskey R, Tatum TC, Bollero GA, Jeschke MR, Tranel PJ (2005) Genome size analysis of weedy species. Crop Sci 45:2557-2562

Reeves RG, Bockholt AJ (1964) Modification and improvement of a maize inbred by crossing it with Tripsacum. Crop Sci 4:7-10
SAGARPA (2012) Acuerdo por el que se determinan Centros de Origen y Diversidad Genetica del maiz. Diario Oficial de la Federacion, viernes 2 de noviembre

Sherman RA, Voigt PW, Burson BL, Dewald CL (1991) Apomixis in diploid $\times$ triploid Tripsacum dactyloides hybrids. Genome 34:528-532

Springer TL, Dewald CL (2004) Eastern gamagrass and other Tripsacum species. In: Moser LE, Burson BL, Sollenberger LE (eds) Warm-season (C4) grasses, Agron. Monogr. No. 45, ASA, Madison, WI, pp 955-974

Talbert LE, Doebley JF, Larson S, Chandler VL (1990) Tripsacum andersonii is a natural hybrid involving Zea and Tripsacum: molecular evidence. Am J Bot 77:722-726

Tiedje JM, Colwell RK, Grossman YL, Hodson RE, Lenski RE, Mack RN, Regal PJ (1989) The planned introduction of genetically engineered organisms: ecological considerations and recommendations. Ecology 1:298-315

USDA NRCS (2015) The PLANTS Database. National Plant Data Team, Greensboro, NC 27401-4901 U. http://plants. usda.gov. Accessed 5 Oct 2015

Whitlock R, Hipperson H, Mannarelli M, Burke T (2008) A high-throughput protocol for extracting high-purity genomic DNA from plants and animals. Mol Ecol Resour 8:736-741

Williamson M (1994) Community response to transgenic plant release: predictions from British experience of invasive plants and feral crop plants. Mol Ecol 3:75-79 